\title{
STUDI VARIASI KEBERANGKATAN LALU LINTAS DAN PERBANDINGAN ARUS JENUH METODE TIME SLICE DENGAN ARUS JENUH MKJI 1997 PADA SIMPANG BERSINYAL DENGAN SHORT TIME COUNTDOWN TIMER
}

\author{
Tri Utamy Yohana Panjaitan', Amirotul MHM²), S J Legowo ${ }^{3)}$ \\ 1) Mahasiswa Fakultas Teknik, Prodi Teknik Sipil, Universitas Sebelas Maret \\ 2)Pengajar Fakultas Teknik, Prodi Teknik Sipil, Universitas Sebelas Maret \\ 3)Pengajar Fakultas Teknik, Prodi Teknik Sipil, Universitas Sebelas Maret \\ Jl. Ir. Sutami 36A, Surakarta, 57126; Telp.0271-634524.yohanapanjaitan17@gmail.com
}

\begin{abstract}
On highway, location which contains conflict points is intersection. One of means of reducing conflict points is by adding traffic lights. Another equipment to possibly be added on intersection is countdown timer. Countdown timer is an additional equipment that can provide informantions on the traffic lights' duration to drivers. On the other side, this addition can cause variation on vehicles departure (Cong dkk; 2012). This research's purposes are knowing the variation of vehicle's departure and base saturation flow per meter ( $\left.S_{0} / m\right)$ on intersections equipped with countdown timer. The datas were collected at Sate Sumber Intersection, Polres Karanganyar Intersection, and Tugu Wisnu Intersection and each were taken at peak and off-peak hour. Vebicle's departure variation data are analyzed by using statistic analysis method while saturation flow datas by using time slice method. Based on analysis result, known variation of vebicle's departure that occur on Sate Sumber Intersection is acceleration of vehicle's departure while on Polres Karanganyar Intersection and Tugu Wisnu Intersection are deceleration of vehicle's departure. From all values of $S_{0} / m$ obtained from all three intersections, none of them correspond the standard of MKJI $1997 \mathrm{~S}_{0} / \mathrm{m}$, which is 600.
\end{abstract}

Keywords: countdown timer, time slice method, departure time shift, short time, signalized intersections, saturation flow

\section{ABSTRAK}

Pada jalan raya, titik konflik yang paling banyak ditemui yaitu pada simpang. Salah satu upaya untuk mengurangi titik konflik adalah dengan penambahan lampu lalu lintas. Perangkat lain yang dapat ditambahkan pada simpang adalah countdown timer. Countdown timer merupakan perangkat tambahan yang berfungsi memberikan informasi mengenai durasi waktu sinyal dari lampu lalu lintas. Akan tetapi, penambahan countdown timer ternyata menyebabkan timbulnya variasi pada keberangkatan lalu lintas atau kendaraan (Cong dkk; 2012). Penelitian ini bertujuan untuk mengetahui variasi pada waktu keberangkatan dan nilai arus jenuh dasar per meter $\left(\mathrm{S}_{0} / \mathrm{m}\right)$ pada simpang bersinyal dengan countdown timer. Data diperoleh di Simpang Sate Sumber, Simpang Polres Karanganyar, dan Simpang Tugu Wisnu yang dilakukan pada jam puncak dan jam tidak puncak. Data variasi waktu keberangkatan dianalisis menggunakan analisis statistic, sementara data arus jenuh meggunakan metode time slice. Berdasarkan hasil analisis, diketahui variasi waktu keberangkatan yang terjadi berupa percepatan waktu keberangkatan pada Simpang Sate Sumber dan perlambatan waktu keberangkatan pada Simpang Polres Karanganyar dan Simpang Tugu Wisnu. Nilai $\mathrm{S}_{0} / \mathrm{m}$ yang diperoleh pada semua simpang baik pada jam puncak tidak ada yang memenuhi standar $\mathrm{S}_{0} / \mathrm{m}$ MKJI 1997 yaitu sebesar 600 .

Kata kunci: countdown timer, metode time slice, variasi waktu keberangkatan, simpang bersinyal, arus jenuh

\section{PENDAHULUAN}

Perkembangan masyarakat yang berlangsung secara pesat mengakibatkan laju pertumbuhan lalu lintas yang terus meningkat. Dengan meningkatnya laju pertumbuhan menyebabkan arus pada lalu lintas jalan raya semakin padat terutama pada simpang yang dimana sering terjadi banyaknya titik konflik. Hal yang dapat dilakukan untuk mengurangi jumlah titik konflik simpang jalan raya adalah dengan penambahan lampu lalu lintas (traffic signa). Upaya untuk meningkatkan kinerja pada simpang bersinyal yang dapat dilakukan salah satunya adalah dengan penambahan alat penunjuk informasi waktu hitung mundur atau yang disebut dengan countdown timer. Penambahan countdown timer pada simpang bersinyal ternyata menyebabkan perubahan perilaku pada pengendara yaitu pengendara akan berangkat lebih dahulu sebelum lampu lalu lintas menunjukkan waktu hijau. Hal inilah yang menyebabkan terjadinya variasi waktu keberangkatan lalu lintas pada simpang bersinyal. Apabila variasi yang terjadi adalah percepatan keberangkatan kendaraan, maka pengendara melakukan pelanggaran pada lalu lintas dan dikhawatirkan dapat menyebabkan potensi 
pelanggaran. Oleh karena itu, perlunya dilakukan analisis variasi waktu keberangkatan lalu lintas pada simpang bersinyal dengan countdown timer untuk mengurangi potensi terjadinya kecelakaan. Selain itu, perlunya dilakukan analisis arus jenuh pada simpang bersinyal dengan countdown timer untuk mengetahui jumlah kendaraan maksimum yang dapat dilewatkan oleh lengan pendekat tiap simpang tinjauan.

Penelitian ini memiliki kemiripan dengan penelitian yang dilakukan Bowoputro (2014) di kota Malang Bagian Selatan dalam menganalisis arus jenuh dasar per meter pada simpang bersinyal. Metode dalam pengumpulan data yang digunakan adalah perekaman dengan kamera video seperti penelitian yang dilakukan oleh Shang (2014). Metode analisis data yang digunakan adalah metode time slice seperti peneliatian sebelumnya yang dilakukan oleh Kurnia (2013) dan Nguyen (2016).

\section{LANDASAN TEORI}

\section{Dasar Teori}

\section{Variasi Waktu Keberangkatan Lalu Lintas}

Rumus yang digunakan dalam perhitungan variasi waktu keberangkatan arus kendaraan adalah sebagai berikut:

Nilai rata-rata (Mean)

$\bar{x}=\frac{1}{n} \sum_{i=1}^{n} x_{i}$

dengan:

$\bar{x}=$ Nilai rata-rata,

$x_{i} \quad=$ Nilai sampel ke-i, dan

$n \quad=$ Jumlah data

Standar Deviasi

$S=\sqrt{\frac{n \sum_{i=1}^{n} x_{i}^{2}-\left(\sum_{i=1}^{n} x_{i}\right)^{2}}{n(n-1)}}$

dengan:

$S \quad=$ Standar deviasi,

$x_{i} \quad=$ Nilai sampel ke-i,

$n \quad=$ Jumlah data

Kuartil

a) untuk n ganjil:

$$
Q_{i}=\frac{i(n+1)}{4}
$$

b) untuk n genap:

$$
Q_{i}=\frac{i(n+2)}{4}
$$

dengan:

$\mathrm{Q}_{\mathrm{i}}=$ Kuartil ke-i, dan

$\mathrm{n}=$ Banyaknya data.

\section{Arus Jenuh}

Rumus yang digunakan dalam perhitungan arus jenuh adalah sebagai berikut:

a) Time Slice

$$
(\Sigma \mathrm{Lv} \times \mathrm{emp} \mathrm{Lv}+\Sigma \mathrm{Hv} \times \mathrm{empHv}+\Sigma \mathrm{Lv} \times \mathrm{emp} \mathrm{Lv}) \times \frac{3600}{\mathrm{t}}=\mathrm{S} .
$$

dengan:

$$
\begin{array}{ll}
S & =\text { Arus jenuh (smp/jam), } \\
\mathrm{t} & =\text { Waktu interval (detik), } \\
e m p & =\text { Nilai ekuivalen, } \\
L V & =\text { Notasi untuk kendaraan ringan, } \\
H V & =\text { Notasi untuk kendaraan berat, dan }
\end{array}
$$


$M C=$ Notasi untuk sepeda motor.

b) MKJI 1997

Arus lalu lintas total (smp/jam)

$Q s m p=(e m p L V \times L V)+(e m p H V \times H V)+(e m p M C \times M C)$

dengan:

$Q=$ Arus lalu lintas total ( $\mathrm{smp} / \mathrm{jam})$,

Arus Jenuh

$\mathrm{S}=\mathrm{S}_{0} \times \mathrm{F}_{\mathrm{CS}} \times \mathrm{F}_{\mathrm{SF}} \times \mathrm{F}_{\mathrm{G}} \times \mathrm{F}_{\mathrm{P}} \times \mathrm{F}_{\mathrm{LT}} \times \mathrm{F}_{\mathrm{RT}}$

dengan:

$\mathrm{S}=$ Arus jenuh (smp/waktu hijau efektif),

$\mathrm{S}_{0}=$ Arus jenuh dasar (smp/waktu hijau efektif),

$\mathrm{F}_{\mathrm{CS}}=$ Faktor koreksi arus jenuh akibat ukuran kota (jumlah penduduk),

$\mathrm{F}_{\mathrm{SF}}=$ Faktor koreksi arus jenuh akibat adanya gangguan samping,

$\mathrm{F}_{\mathrm{G}}=$ Faktor koreksi arus jenuh akibat kelandaian jalan,

$\mathrm{F}_{\mathrm{P}}=$ Faktor koreksi arus jenuh akibat adanya kegiatan perparkiran dekat lengan persimpangan,

$\mathrm{F}_{\mathrm{LT}}=$ Faktor koreksi kapasitas akibat adanya pergerakan belok kiri, dan

$\mathrm{F}_{\mathrm{RT}}=$ Faktor koreksi kapasitas akibat adanya pergerakan belok kanan.

Arus Jenuh Dasar

$\mathrm{S}_{0}=600 \times \mathrm{XW}$

dengan:

$\mathrm{S}_{0}=$ Arus jenuh dasar (smp/waktu hijau efektif),

$600=$ Arus jenuh dasar per meter $\left(\mathrm{S}_{0} / \mathrm{m}\right)$, dan

$\mathrm{W}_{\mathrm{e}}=$ Lebar efektif (meter).

\section{METODE}

\section{Lokasi dan Waktu Penelitian}

Lokasi penelitian dilaksanakan di Kota Surakarta dan Kabupaten Karanganyar. Simpang bersinyal yang dipilih adalah Simpang Sate Sumber (pendekat Jl. Ki Mangun Sarkoro arah barat), Simpang Polres Karanganyar (pendekat Jl. Lawu arah barat, dan Simpang Tugu Wisnu (pendekat Jl. Semarang - Surakarta arah utara). Waktu penelitian yang digunakan adalah saat jam puncak $(06.30-08.00)$ dan jam tidak puncak $(10.00-11.00)$

\section{Jenis Data}

Pada penelitian ini digunakan data primer dan data sekunder. Data primer merupakan data yang diperoleh secara langsung oleh penulis dengan cara survei langsung pada pendekat simpang yang telah ditentukan yang berupa data geometri jalan (kemiringan dan lebar pendekat), data arus lalu lintas, data durasi waktu sinyal, data hambatan samping, dan data kondisi lingkungan jalan. Sedangkan data sekunder adalah data yang didapatkan dari sumber lain seperti instansi pemerintah dan instansi swasta yang merupakan journal penelitian, jumlah penduduk dan peta jaringan jalan Kota Solo dan Kabupaten Karanganyar.

\section{Pengumpulan Data}

Data geoemetrik jalan raya dilakukan dengan cara pengukuran langsung pada lapangan, sebagai contoh data lebar pendekat diukur menggunakan meteran dan data kemiringan jalan diukur menggunakan Total Station. Data arus lalu lintas dan durasi waktu sinyal diperoleh melalui rekaman video pada simpang. Data hambatan samping dan data kondisi lingkungan jalan diperoleh melalui pengamatan secara langsung di lapangan.

\section{ANALISIS DAN HASIL}

\section{Analisis Variasi Waktu Keberangkatan}

Pada analisis pergeseran waktu keberangkatan, banyak kejadian / frekuensi waktu berangkat kendaraan dikelompokkan dan disajikan dalam bentuk grafik. Hal ini dimaksudkan untuk melihat besar pergeseran waktu keberangkatan dan perbandingannya dengan tiap simpang. Apabila kendaraan bergerak sebelum 
waktu hijau maka waktu keberangkatan ditunjukkan dengan nilai negatif, sementara apabila kendaraan bergerak setelah waktu hijau makan waktu keberangkatan ditunjukkan dengan nilai positif.

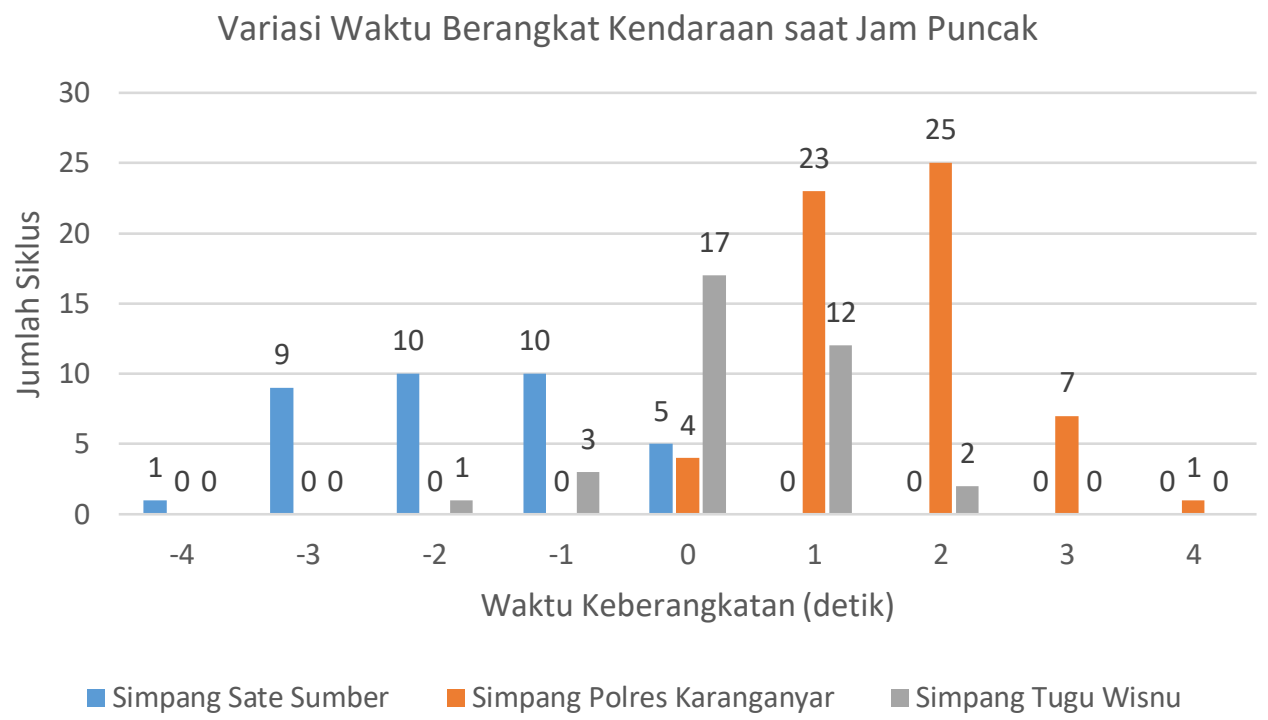

Gambar 1 Grafik Variasi Waktu Berangkat Kendaraan saat Jam Puncak

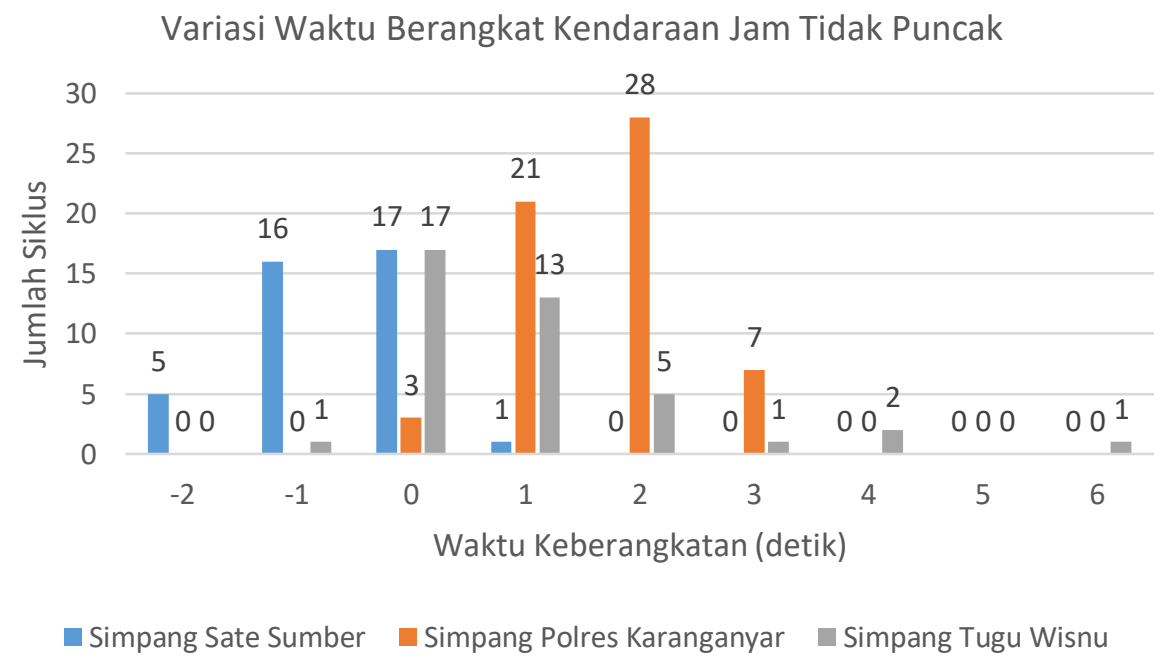

Gambar 2 Grafik Variasi Waktu Berangkat Kendaraan saat Jam Tidak Puncak

Berdasarkan gambar 1, saat jam puncak dapat diketahui bahwa potensi terjadinya pelanggaran lebih tinggi di Simpang Sate Sumber ditunjukkan dengan hampir semua siklus yang berangkat sebelum waktu hijau. Sementara untuk Simpang Polres Karanganyar dan Tugu Wisnu hampir seluruh siklus berangkat sesaat atau setelah waktu hijau. Hal ini menunjukkan pada Simpang Sate Sumber terjadi percepatan waktu keberangkatan dan perlambatan waktu keberangkatan pada Simpang Polres Karanganyar dan Simpang Tugu Wisnu.

Sementara saat jam tidak puncak menurut gambar 2, potensi terjadinya pelanggaran lebih tinggi di Simpang Sate Sumber ditunjukkan dengan hampir semua siklus yang berangkat sebelum waktu hijau. Sementara untuk Simpang Polres Karanganyar dan Tugu Wisnu hampir seluruh siklus berangkat sesaat atau setelah waktu hijau. Hal ini menunjukkan pada Simpang Sate Sumber terjadi percepatan waktu keberangkatan dan perlambatan waktu keberangkatan pada Simpang Polres Karanganyar dan Simpang Tugu Wisnu 


\section{Analisis Mean dan Standar Deviasi Waktu Keberangkatan}

Hasil perhitungan mean dan standar deviasi pada tiap simpang dapat dilihat pada Tabel 1

Tabel 1 Hasil Perhitungan Mean dan Standar Deviasi pada Simpang

\begin{tabular}{ccccccc}
\hline Nama Simpang & Jumlah & Mean & Standar & $\mathbf{Q}_{1}$ & $\mathbf{Q}_{3}$ & Indikasi \\
& Data & & Deviasi & $\begin{array}{c}\text { (Kuartil } \\
\text { (Kuartil }\end{array}$ & data \\
& & & atas) & bawah) & \\
& & & & &
\end{tabular}

\begin{tabular}{ccccccc}
\hline & \multicolumn{7}{c}{ Jam Puncak } \\
\hline Simpang Sate Sumber & 35 & $-1,74$ & 1,09 & -3 & -1 & buruk \\
\hline $\begin{array}{c}\text { Simpang Polres } \\
\text { Karanganyar }\end{array}$ & 60 & 1,63 & 0,84 & 1 & 2 & buruk \\
Simpang Tugu Wisnu & 35 & 0,31 & 0,83 & 0 & 1 & baik \\
\hline Simpang Sate Sumber & 39 & $-0,64$ & 0,74 & -1 & 0 & buruk \\
\hline $\begin{array}{c}\text { Simpang Polres } \\
\text { Karanganyar }\end{array}$ & 59 & 1,66 & 0,76 & 1 & 2 & buruk \\
\hline Simpang Tugu Wisnu & 40 & 0,98 & 1,37 & 0 & 1 & buruk \\
\hline
\end{tabular}

Apabila standar deviasi lebih besar dari mean, maka data bervariasi. Berdasarkan Tabel 1 Simpang Tugu Wisnu saat jam puncak maupun jam tidak puncak dan Simpang Sate Sumber saat jam tidak puncak memiliki standar deviasi yang lebih besar dari mean. Hal ini menunjukkan bahwa data penelitian pada Simpang Sate Sumber saat jam tidak puncak dan Simpang Tugu Wisnu saat jam puncak maupun jam tidak puncak memiliki data yang bervariasi.

Contoh perhitungan mean dan st. deviasi pada Simpang Sate Sumber saat jam puncak adalah sebagai berikut:

Data

$$
=-1,-2,-1,-1,-3,-1,0,-1,-1,-1,0,-2,0,-2,-2,-2,-3,-3,-4,-2,-2,0,-1,-3,-3,-3,-3,0 \text {, }
$$

Mean

$$
\begin{aligned}
& -1,-2,-1,-3,-3,-2,-2 \\
= & \frac{1}{n} \sum_{i=1}^{n} x_{i} \\
= & \frac{1}{35} \sum_{1}^{35} x_{i} \\
= & -1,74 \\
= & \sqrt{\frac{n \sum_{i=1}^{n} x_{i}^{2}-\left(\sum_{i=1}^{n} x_{i}\right)^{2}}{n(n-1)}} \\
= & \sqrt{\frac{35 \sum_{1}^{35} x_{i}^{2}-\left(\sum_{1}^{35} x_{i}\right)^{2}}{35(35-1)}} \\
= & 1,09
\end{aligned}
$$

St. Deviasi

Selain itu juga dapat dilihat melalui hubungan antara standar deviasi dan kuartil. Menurut Faisal (2016), apabila standar deviasi berada di antara kuartil bawah dan kuartil atas maka data dapat dikatakan data baik. Sementara jika standar deviasi berada di luar kuartil bawah dan kuartil atas maka data dapat dikatakan data buruk. Menurut Tabel 1 data baik hanya didapati pada Simpang Tugu Wisnu saat jam puncak.

Contoh perhitungan kuartil pada Simpang Sate Sumber saat jam puncak adalah sebagai berikut: 


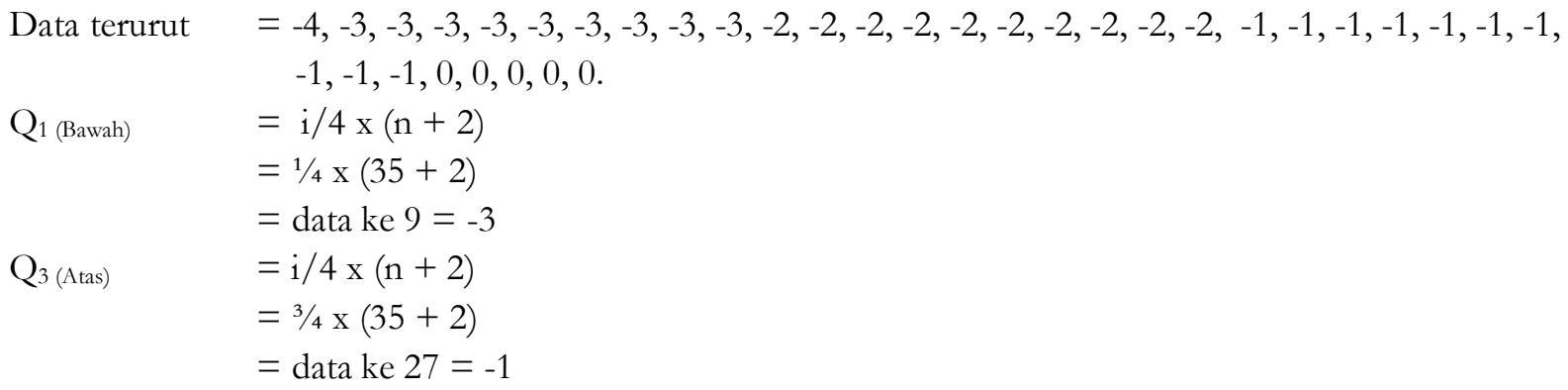

1) Analisis Korelasi Waktu Keberangkatan dengan Faktor Penyesuaian

Berikut merupakan faktor-faktor penyesuaian yang mempengaruhi terjadinya variasi waktu keberangkatan pada Simpang Sate Sumber, Simpang Polres Karanganyar, dan Simpang Tugu Wisnu.

a) Durasi Waktu Hijau

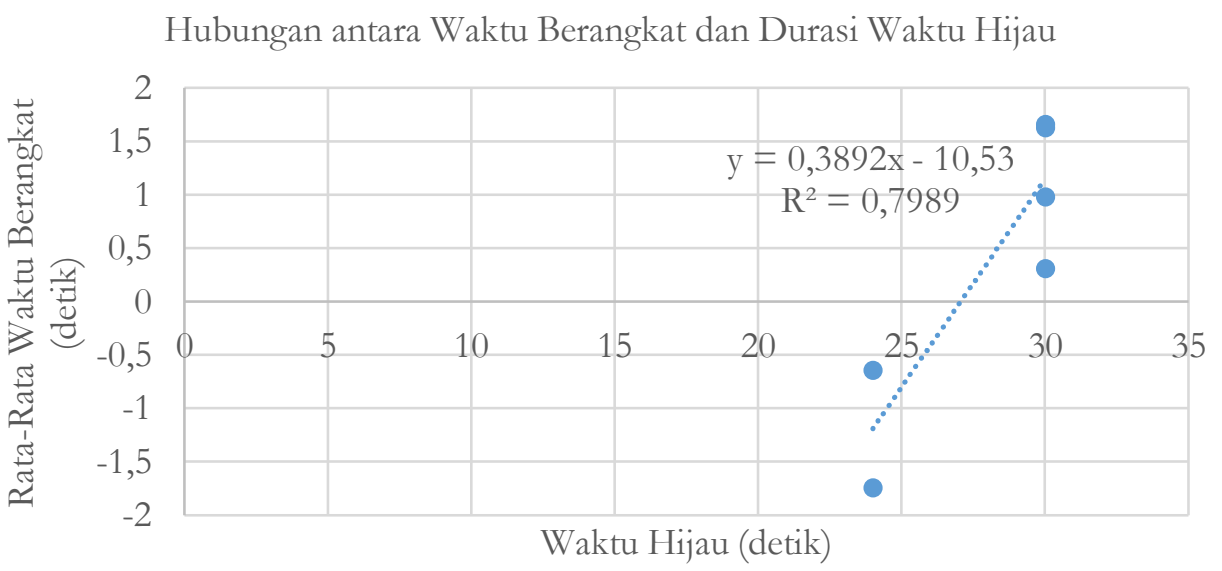

Gambar 3 Hubungan Waktu Keberangkatan Arus Kendaraan dengan Durasi Waktu Hijau

b) Komposisi Motorcycle (MC)

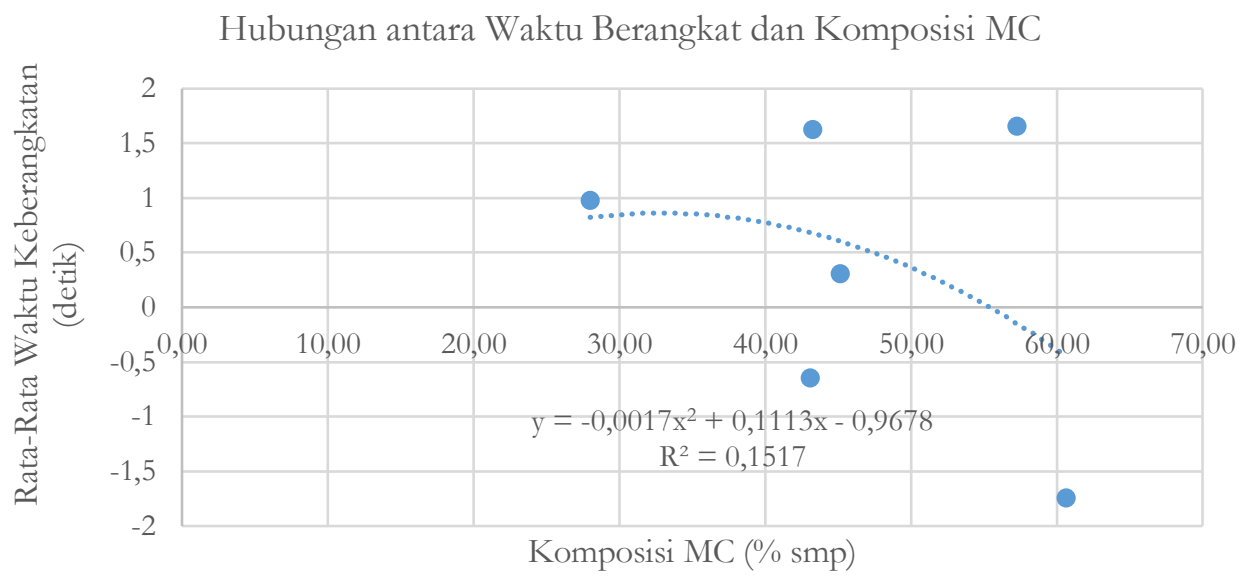

Gambar 4 Hubungan Waktu Keberangkatan Arus Kendaraan dengan Komposisi MC 
c) Komposisi Light Vebicle (LV)

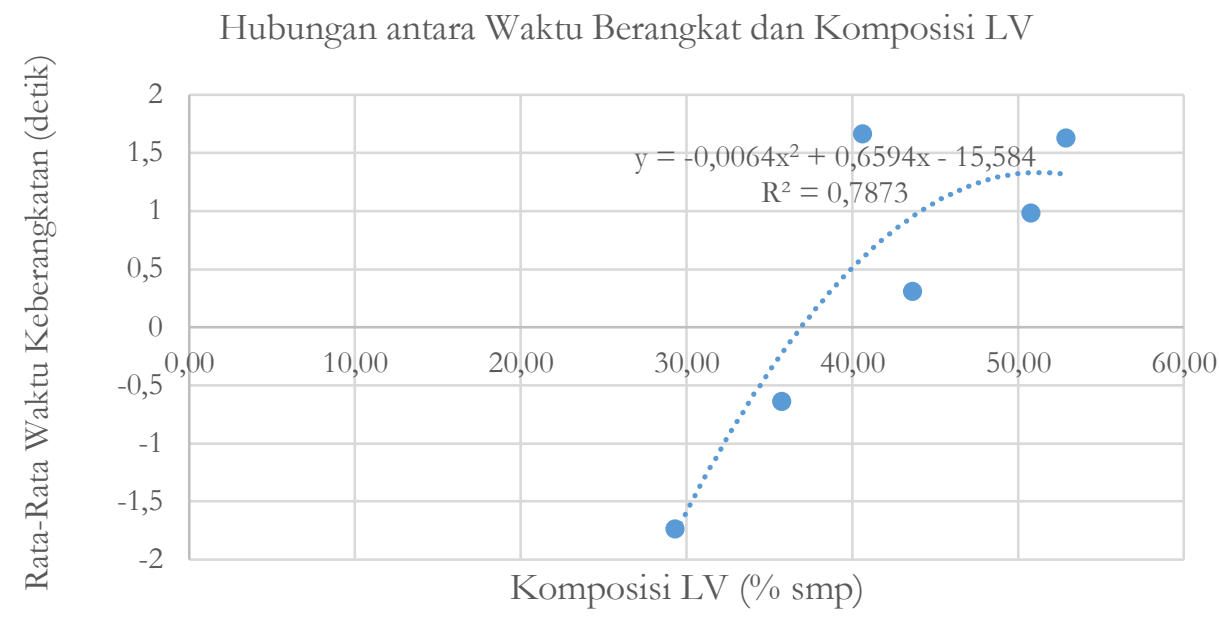

Gambar 5 Hubungan Waktu Keberangkatan Arus Kendaraan dengan Komposisi LV d) Komposisi Heavy Vebicle (HV)

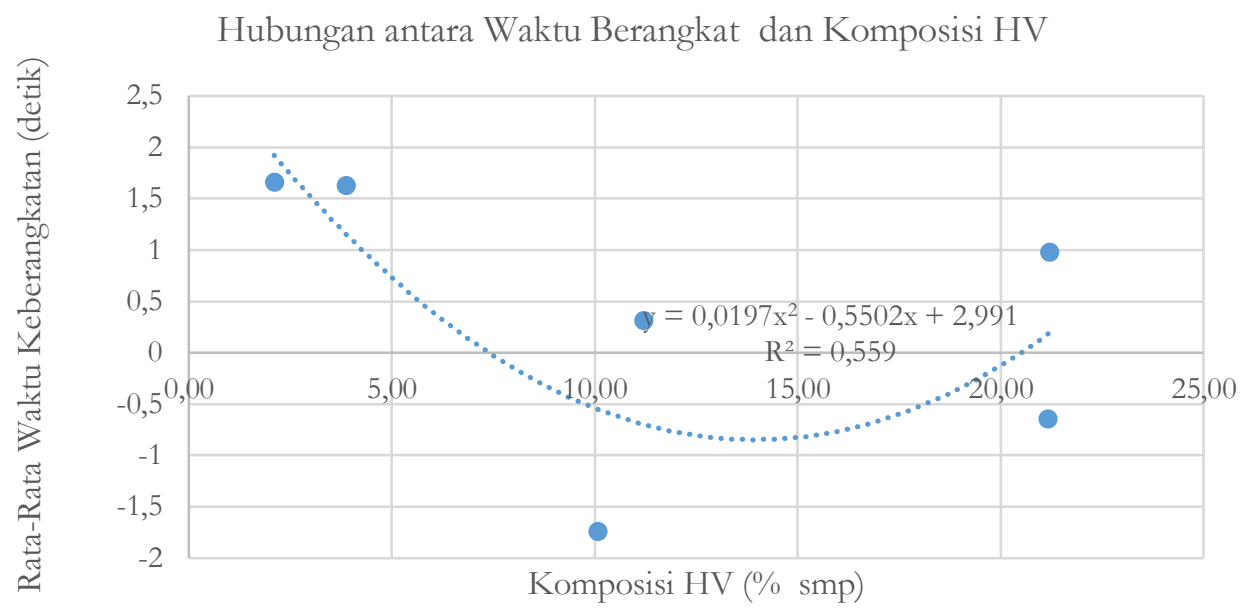

Gambar 6 Hubungan Waktu Keberangkatan Arus Kendaraan dengan Komposisi HV 
e) Arus Jenuh Dasar Per Meter $\left(\mathrm{S}_{\mathrm{o}} / \mathrm{m}\right)$

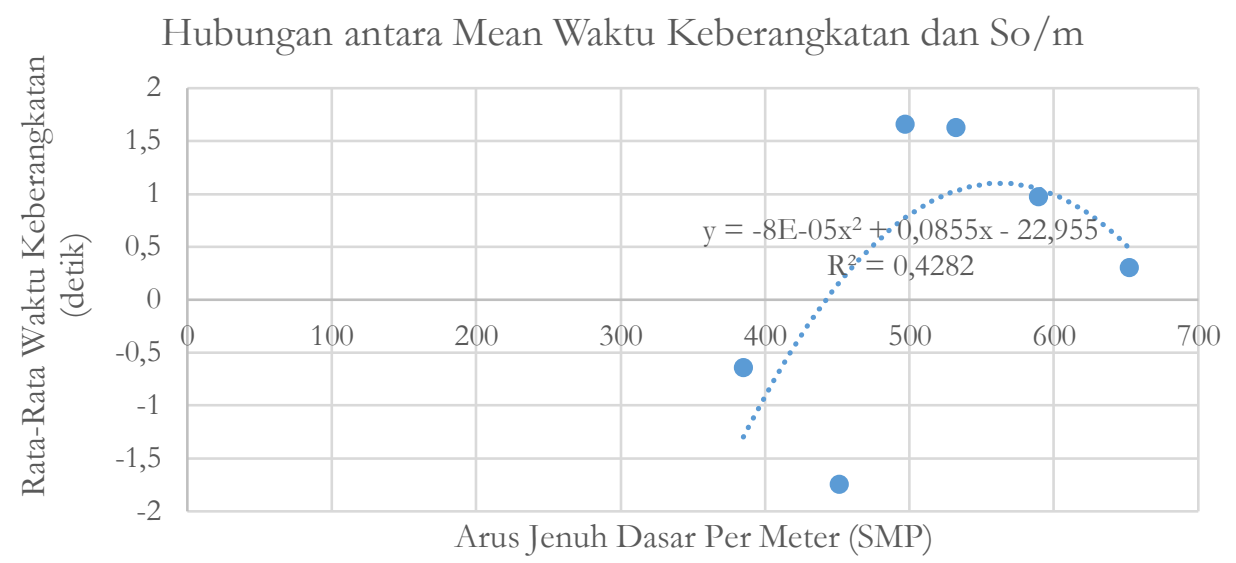

Gambar 7 Hubungan Waktu Keberangkatan Arus Kendaraan dengan Komposisi MC

Berdasarkan Gambar 3 - 7 dapat dilihat nilai koefesien determinasi $\left(\mathrm{R}^{2}\right)$ untuk faktor-faktor yang kemungkinan mempengaruhi terjadinya variasi waktu keberangkatan. Dengan menghitung akar pangkat dari nilai koefisien determinasi dapat diperoleh nilai koefisien korelasi (R). Koefesien korelasi adalah nilai yang menunjukkan seberapa kuat hubungan antar variabel. Menurut Sarwono (2006), kriteria koefisien korelasi sebagai berikut:

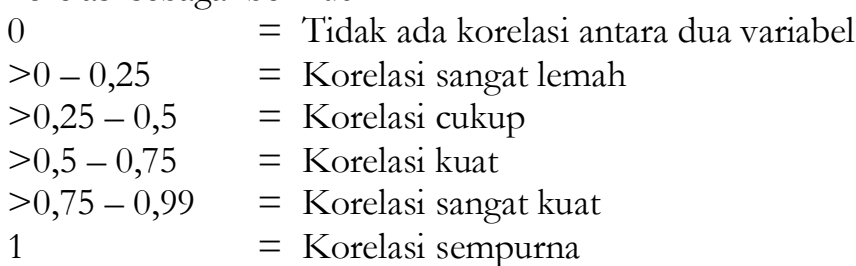

Besarnya korelasi antara Waktu Keberangkatan dengan masing-masing faktor penyesuaian dapat dilihat pada Tabel 2

Tabel 2 Analisis Korelasi Waktu Keberangkatan dengan Faktor-Faktor Penyesuaian

Faktor Penyesuaian Waktu

Koefisien Korelasi

Keterangan Korelasi

Keberangkatan

\begin{tabular}{lcc}
\hline Durasi Waktu Hijau & 0,8938 & Sangat kuat \\
\hline Komposisi MC & 0,3895 & Cukup \\
\hline Komposisi LV & 0,8873 & Sangat kuat \\
\hline Komposisi HV & 0,7477 & Kuat \\
\hline Arus Jenuh Dasar per Meter & 0,6544 & Kuat \\
\hline
\end{tabular}

Dengan ini dapat disimpulkan bahwa, variabel yang memberikan pengaruh paling kuat terhadap waktu keberangkatan adalah durasi waktu hijau, komposisi LV, dan komposisi HV. Selanjutnya diikuti oleh 
komposisi $\mathrm{HV}$ dan $\mathrm{S}_{\mathrm{o}} / \mathrm{m}$ yang memberikan pengaruh kuat terhadap waktu keberangkatan. Pada posisi terakhir komposisi $\mathrm{MC}$ hanya memberikan pengaruh yang cukup terhadap waktu keberangkatan.

\section{Analisis Arus Jenuh}

Menurut MKJI 1997, nilai $\mathrm{S}_{\mathrm{o}} / \mathrm{m}$ dapat dilihat melalui persamaan berikut:

$\mathrm{S}_{0} \quad=600 \times \mathrm{W}_{\text {efektif }}$

600 adalah nilai $\mathrm{S}_{\circ} / \mathrm{m}$ yang disarankan oleh MKJI 1997. Salah satu tujuan penelitian ini adalah untuk mengetahui apakah nilai 600 adalah nilai yang akan dihasilkan oleh semua simpang. Oleh karena itu, dilakukan perhitungan $\mathrm{S}_{\mathrm{o}} / \mathrm{m}$ pada Simpang Sate Sumber, Simpang Polres Karanganyar, Simpang Tugu Wisnu baik saat jam puncak maupun tidak puncak.

Contoh perhitungan $\mathrm{S}_{\mathrm{o}} / \mathrm{m}$ pada Simpang Sate Sumber saat jam puncak sebagai berikut:

$$
\begin{aligned}
\mathrm{S}_{0} & =\mathrm{S}_{\mathrm{o}} / \mathrm{m} \mathrm{W}_{\text {efektif }} \\
\mathrm{S}_{\mathrm{o}} / \mathrm{m} & =\mathrm{S}_{\mathrm{o}} / \mathrm{W}_{\text {efektif }} \\
\mathrm{S}_{\mathrm{o}} / \mathrm{m} & =2929 / 6,5 \\
& =451
\end{aligned}
$$

\begin{tabular}{|c|c|c|c|}
\hline Nama Simpang & $\begin{array}{c}\text { Lebar Pendekat } \\
\text { (m) }\end{array}$ & $\mathrm{S}_{\mathrm{o}}(\mathrm{smp} / \mathrm{jam})$ & $\mathrm{S}_{\mathrm{o}} / \mathrm{m}(\mathrm{smp})$ \\
\hline \multicolumn{4}{|c|}{ Jam Puncak } \\
\hline Sate Sumber & 6,5 & 2929 & 451 \\
\hline Polres & 6 & 3189 & 532 \\
\hline \multicolumn{4}{|l|}{ Karanganyar } \\
\hline Tugu Wisnu & 5 & 3259 & 652 \\
\hline \multicolumn{4}{|c|}{ Jam Tidak Puncak } \\
\hline Sate Sumber & 6,5 & 2506 & 385 \\
\hline Polres & 6 & 2984 & 497 \\
\hline \multicolumn{4}{|l|}{ Karanganyar } \\
\hline Tugu Wisnu & 5 & 2943 & 589 \\
\hline
\end{tabular}

Tabel 3 Arus Jenuh Dasar pada Tiap Simpang

Berdasarkan hasil perhitungan pada Tabel 3 di atas didapatkan 6 nilai $\mathrm{S}_{\circ} / \mathrm{m}$ dari hasil survey 3 simpang saat jam puncak dan tidak puncak. 1 dari 6 hasil perhitungan $\mathrm{S}_{\mathrm{o}} / \mathrm{m}$ lebih besar dari 600 (standar yang ditetapkan MKJI 1997) yaitu sebesar 652. Sementara hasil perhitungan lainnya berada dibawah standar dengan range 385 - 589. Perbedaan hasil yang bervariasi ini menunjukkan bahwa $\mathrm{S}_{\mathrm{o}} / \mathrm{m}$ dilapangan tidak dapat serta merta dianggap sebesar 600 karena banyaknya faktor-faktor yang terjadi dilapangan yang tidak dapat diabaikan. Arus lalu lintas, hambatan samping, waktu fase, jenis kendaraan, distribusi pergerakan kendaraan dan kondisi geometri memberikan pengaruh terhadap besar $\mathrm{S}_{\mathrm{o}} / \mathrm{m}$ pada simpang.

\section{SIMPULAN}

a. Waktu Berangkat Kendaraan:

1. Saat jam puncak, waktu keberangkatan pada Simpang Sate Sumber memiliki potensi pelanggaran dan terjadi percepatan waktu keberangkatan. Sementara pada Simpang Polres Karanganyar dan Simpang Tugu Wisnu tidak ada potensi pelanggaran namun terjadinya perlambatan waktu keberangkatan. 
2. Saat jam tidak puncak, waktu keberangkatan pada Simpang Sate Sumber memiliki potensi pelanggaran dan terjadi percepatan waktu keberangkatan. Sementara pada Simpang Polres Karanganyar dan Simpang Tugu Wisnu tidak ada potensi pelanggaran namun terjadinya perlambatan waktu keberangkatan.

3. Variabel yang memberikan pengaruh terhadap waktu keberangkatan adalah durasi waktu hijau, komposisi LV, komposisi HV, dan arus jenuh dasar per meter

b. Arus Jenuh Dasar per Meter:

Berdasarkan hasil analisis survey 3 simpang saat jam puncak dan tidak puncak, 1 dari 6 hasil perhitungan $\mathrm{S}_{\mathrm{o}} / \mathrm{m}$ lebih besar dari 600 (standar yang ditetapkan MKJI 1997) yaitu sebesar 652. Sementara hasil perhitungan lainnya berada dibawah standar dengan range 385 - 589. Hal ini disebabkan adanya faktorfaktor yang terjadi di lapangan yang mempengaruhi nilai arus jenuh dasar per meter pada masing-masing simpang

\section{SARAN}

1. Untuk penelitian selanjutnya disarankan dilakukan analisis terhadap jumlah pelanggaran yang terjadi pada simpang. Hal ini dimaksudkan untuk memberi gambaran yang lebih jelas mengenai potensi pelanggaran pada simpang bersinyal yang dilengkapi dengan short time countdown timer.

2. Standar MKJI 1997 arus jenuh dasar pe meter sebesar $600 \mathrm{smp}$ sebaiknya dikaji ulang. Nilai tersebut tidak dapat diapilikasikan kepada seluruh simpang. Hal ini disebabkan terdapat berbagai faktor-faktor penyesuaian yang berbeda pada tiap lokasi simpang

\section{REFERENSI}

2012. Buku Pedoman Penulisan Skripsi/Tugas Akbir Jurusan Teknik Sipil Fakultas Teknik Universitas Sebelas Maret. Universitas Sebelas Maret.

1997. Manual Kapasitas Jalan Indonesia (MKJI). Departemen Pekerjaan Umum Direktorat Jenderal Bina Marga.

Bowoputro, Hendi, M.Zainul Arifin, Lutfi Djakfar, dan Rahayu Kusumaningrum. 2014. Kajian Arus Jenub Pada Simpang Bersinyal di Kota Malang Bagian Selatan. Jurnal Rekayasa Sipil Volume 8, No.2 - 2014 ISSN 1978 - 5658.

Cong, Z., Yongfeng, M., \& Jian, L., 2012, Study On Start-up Lost Time of Traffic Signal with Countdown Display and the Driving Behavior at the End of Green Signal, Proceeding of The 12th International Conference of Transportation Profesionals, pp. 941-952.

Faisal, M Reza. 2016. Seri Belajar Pemograman: Pengenalan Bahasa Pemograman. R. INDC.

Ghozali, Imam. 2009. Apilikasi Analisis Multivariate dengan Program SPSS. Semarang: UNDIP.

Jonathan, Sarwono. 2006. Metode Penelitian Kuantitatif dan Kualitatif. Yogyakarta: Graha Ilmu.

Lubis, Rozaqon Insani, dan Medis S. Surbakti. 2016. Analisa Arus Jenub Dan Panjang Antrian Pada Simpang Bersinyal Dan Mikrosimulasi Menggunakan Software Vissim . Jurnal Rekayasa Sipil Volume 8, No.2 - 2016 ISSN 1978 - 5658

Nguyen, Huynh Duc. 2016. Saturation Flow Rate Analysis at Signalized Intersections for Mixed Traffic Conditions in Motorcycle Dependent Cities. Transportation Research Procedia 2016, Volume 15, Pages 694-708

Shang, Huayan, Yiming Zhang, and Lang Fan. 2014. Heterogeneous Lanes' Saturation Flow Rates at Signalized Intersections. Procedia - Social and Behavioral Sciences 138 ( 2014) $3-10$

W, Lila Kurnia, Achmad Wicaksono, dan M. Ruslin Anwar. 2013. Analysis Of Motorycle Effects To Saturation Flow Rate At Signalized Intersections In Malang City. Jurnal Rekayasa Sipil / Volume 7, No.3 - 2013 ISSN 1978 - 5658. 